\title{
The cause of neural tube defects: some experiments and a hypothesis
}

\author{
MARY J SELLER \\ From the Paediatric Research Unit, The Prince Philip Research Laboratories, Guy's Hospital Medical School, \\ London SE1 9RT.
}

SUMmARY The mouse mutant curly-tail is an animal model for human neural tube defects (NTD). Around $60 \%$ spontaneously have NTD. It has been found that maternal administration of hydroxyurea, mitomycin $\mathrm{C}$, or 5-fluorouracil on day 9 of pregnancy, that is, when the fetal neural tube is in the final stages of closure, leads to a significant reduction in the proportion of NTD (to 15 to $20 \%$ ) in the offspring, while total litter size is unaffected. All these substances are inhibitors of DNA synthesis, yet are apparently beneficial to subjects predisposed to NTD. As a consequence, it is suggested that the underlying mechanism causing NTD in the mice, and also in man, is a basic metabolic defect in DNA synthesis which affects cell replication and results in abnormal morphogenesis of the neuraxis.

Neural tube defects (NTD) constitute one of the most common congenital abnormalities in the United Kingdom. Their origin is generally accepted as being multifactorial, ${ }^{1}$ involving a genetic predisposition and environmental triggering factors, but, despite extensive studies, the precise cause is not known and the pathogenesis equally obscure. A recent major advance has been the discovery that recurrences of these defects can largely be prevented by administration in the periconceptional period of multivitamins ${ }^{2}{ }^{3}$ or perhaps folic acid. ${ }^{4}$ However, the underlying mechanism which results in NTD remains unknown. Although the final proof can only come from studies in man, the investigation of pathogenesis is difficult and perhaps even impossible in man and an animal model for these purposes is essential.

Around $60 \%$ of the mouse mutant curly-tail have an NTD of some kind, either exencephaly, spina bifida aperta, or a curly-tail that arises because of delayed closure of the posterior neuropore. ${ }^{5}$ All mice are homozygous recessive for the curly-tail gene, which arose as a spontaneous mutation in 1950 , but the penetrance is reduced to around $60 \%$ because of the action of modifiers in the rest of the genome. ${ }^{6}$ ?

In their presentation and secondary effects at least, the NTD of the curly-tail mice have many

Received for publication 8 January 1983.

Accepted for publication 22 February 1983. points of similarity with human NTD. ${ }^{8}$ In particular, there is a female excess in those affected which is especially marked in exencephaly (the rodent form of anencephaly) ${ }^{7}$; the amniotic fluid AFP levels are raised where the fetuses have open lesions; there is often polyhydramnios ${ }^{9}$; hydrocephalus may develop in survivors with spina bifida; and, finally, there are no other associated major abnormalities. In man, although NTD may occur together with other anomalies such as cleft lip or omphalocele, more commonly spina bifida or anencephaly is an isolated defect. The isolated NTD in the curly-tail mice represent a sharp distinction from other animal models hitherto often used to study the cause of NTD, where both NTD and other abnormalities are induced (in otherwise normal mice) by large doses of teratogens. While accepting that there are limitations, probably especially of causes, I submit that the curly-tail mouse is a valid model in which to study human NTD, and in particular their pathogenesis.

These mice have already been used to provide some insight into the way that both maternal and fetal genes and an environmental component may contribute to the production of NTD. ${ }^{10-14}$ I summarise here recent experiments which have pointed more specifically to possible mechanisms involved in the condition, and which have led me to elaborate a hypothesis concerning the pathogenesis of NTD. 
The experiments were part of a series involving the introduction into the pregnant curly-tail mouse, during the sensitive phase of neural tube formation in her offspring, of agents which are proven both to be teratogenic to the rodent central nervous system and to have a known biochemical effect on a specific metabolic pathway. It was proposed to use smaller amounts of these agents than were necessary to produce NTD in animals not genetically predisposed to the condition, hoping thereby that any agent which then increased the proportion of NTD in the curly-tail mice would imply that there was a geneenvironment interaction, and so give some indication of which biochemical pathway was important in pathogenesis.

Numerous different agents were tested to no effect, but two, hydroxyurea and mitomycin C, when administered on day 9 of pregnancy gave results which were completely the opposite of those expected. This led to the hypothesis being formulated and then tested by a further series of experiments using 5-fluorouracil.

\section{Materials and methods}

CBA/Gr-ct/ct males and young, adult, virgin females were housed together under a harem system, and the females examined each day for vaginal plugs (day of plug = day 0 of pregnancy). On day 9 of gestation, each female received a single intraperitoneal injection, either of one of the substances mentioned below, dissolved in saline, or an equivalent volume of saline. On day 9 in the curly-tail mouse, the neural tube is largely formed and there is final fusion and closure of the neuropores. ${ }^{15}$

The pregnancy was then allowed to continue until day 16 , when the mother was killed, the number of live embryos and resorptions (intrauterine deaths) noted, and the embryos examined for any developmental abnormalities.

The following substances and doses were injected: hydroxyurea, 200, 400,500, and $600 \mathrm{mg} / \mathrm{kg}$ (this forms part of a paper published previously ${ }^{16}$ ); mitomycin $\mathrm{C}, 1,2,4$, and $6 \mathrm{mg} / \mathrm{kg}$; and 5-fluorouracil, $0 \cdot 1,0 \cdot 25,0 \cdot 4,0 \cdot 5,0 \cdot 6,0 \cdot 7$, and $0.8 \mathrm{mg} / \mathrm{kg}$.

The results were analysed statistically comparing drug treated animals with their appropriate controls using a $2 \times 2$ contingency table for the actual numbers obtained.

\section{Results}

Any mouse having exencephaly, lumbosacral or caudal spina bifida, or a curly-tail is described as 'affected' or 'having an NTD'. As can be seen from the controls in the experiments, around $60 \%$ (range 54 to $70 \%$ ) of untreated curly-tail mice exhibit this phenotype; the remainder, although having the curly-tail genotype, do not express it and so have a normal phenotype.

The effect of injecting hydroxyurea into the curlytail mouse on day 9 of pregnancy on the incidence of NTD in the embryos is shown in table 1. A dose

TABLE 1 The effect of administration of various doses of hydroxyurea to curly-tail mice on day 9 of pregnancy on the incidence of neural tube defects in the embryos*.

\begin{tabular}{|c|c|c|c|c|c|}
\hline & \multirow{2}{*}{$\begin{array}{l}\text { Saline } \\
\text { controls }\end{array}$} & \multicolumn{4}{|c|}{ Hydroxyurea $(\mathrm{mg} / \mathrm{kg})$} \\
\hline & & 200 & 400 & 500 & 600 \\
\hline $\begin{array}{l}\text { No of litters } \\
\text { No of live embryos } \\
\text { Mean litter size } \\
\text { No of resorptions }(\%) \\
\text { No of NTD }(\%)\end{array}$ & $\begin{array}{c}21 \\
120 \\
5 \cdot 7 \\
6(5) \\
65(54)\end{array}$ & $\begin{array}{l}9 \\
58 \\
6 \cdot 4 \\
9(13) \\
33(57)\end{array}$ & $\begin{array}{l}12 \\
67 \\
5 \cdot 6 \\
14(17) \\
18(27)\end{array}$ & $\begin{array}{l}11 \\
64 \\
5 \cdot 8 \\
5(8) \\
24(38)\end{array}$ & $\begin{array}{l}4 \\
25 \\
6 \cdot 3 \\
0(0) \\
6(24)\end{array}$ \\
\hline
\end{tabular}

*Adapted from Seller and Perkins. ${ }^{16}$

TABLE 2 The effect of administration of various doses of mitomycin $C$ to curly-tail mice on day 9 of pregnancy on the incidence of neural tube defects in the embryos.

\begin{tabular}{|c|c|c|c|c|c|}
\hline & \multirow{2}{*}{$\begin{array}{l}\text { Saline } \\
\text { controls } \\
\text { pooled }\end{array}$} & \multicolumn{4}{|c|}{ Mitomycin C $(\mathrm{mg} / \mathrm{kg})$} \\
\hline & & 1 & 2 & 4 & 6 \\
\hline $\begin{array}{l}\text { No of litters } \\
\text { No of live embryos } \\
\text { Mean litter size } \\
\text { No of resorptions }(\%) \\
\text { No of NTD }(\%)\end{array}$ & $\begin{array}{c}23 \\
158 \\
6 \cdot 9 \\
23(8) \\
98(62)^{*}\end{array}$ & $\begin{array}{c}9 \\
75 \\
8 \cdot 3 \\
2(3) \\
32(43)\end{array}$ & $\begin{array}{l}8 \\
53 \\
6 \cdot 6 \\
2(2) \\
8(15)\end{array}$ & $\begin{array}{c}10 \\
64 \\
6 \cdot 4 \\
6(9) \\
12(19)\end{array}$ & $\begin{array}{c}7 \\
59 \\
8 \cdot 4 \\
7(11) \\
12(20)\end{array}$ \\
\hline
\end{tabular}

*Range of NTD between experiments: 58 to $70 \%$. 
TABLE 3 The effect of the administration of various doses of 5-fluorouracil to curly-tail mice on day 9 of pregnancy on the incidence of neural tube defects in the embryos.

\begin{tabular}{|c|c|c|c|c|c|c|c|c|}
\hline & \multirow{2}{*}{$\begin{array}{l}\text { Saline } \\
\text { controls } \\
\text { (pooled) }\end{array}$} & \multicolumn{7}{|c|}{ 5-fluorouracil ( $\mathrm{mg} / \mathrm{kg})$} \\
\hline & & $0 \cdot 1$ & $0 \cdot 25$ & 0.4 & $0 \cdot 5$ & $0 \cdot 6$ & $0 \cdot 7$ & $0 \cdot 8$ \\
\hline $\begin{array}{l}\text { No of litters } \\
\text { No of live embryos } \\
\text { Mean litter size } \\
\text { No of resorptions }(\%) \\
\text { No of NTD }(\%)\end{array}$ & $\begin{array}{c}31 \\
213 \\
6 \cdot 9 \\
16(7) \\
135(63)^{*}\end{array}$ & $\begin{array}{l}5 \\
40 \\
8 \cdot 0 \\
1(2) \\
28(70)\end{array}$ & $\begin{array}{c}7 \\
53 \\
7 \cdot 6 \\
3(5) \\
35(66)\end{array}$ & $\begin{array}{c}6 \\
37 \\
6 \cdot 2 \\
3(7) \\
20(54)\end{array}$ & $\begin{array}{l}6 \\
43 \\
7 \cdot 2 \\
6(12) \\
22(51)\end{array}$ & $\begin{array}{l}7 \\
45 \\
6 \cdot 4 \\
7(13) \\
16(36)\end{array}$ & $\begin{array}{l}12 \\
70 \\
5 \cdot 8 \\
18(20) \\
14(20)\end{array}$ & $\begin{array}{l}9 \\
31 \\
3 \cdot 4 \\
32(51) \\
4(13)\end{array}$ \\
\hline
\end{tabular}

* Range of NTD between experiments: 58 to $70 \%$.

of $200 \mathrm{mg} / \mathrm{kg}$ did not alter the incidence but 400,500 , and $600 \mathrm{mg} / \mathrm{kg}$ significantly reduced the number of NTD to $27 \%, 38 \%$, and $24 \%$ respectively $(\mathrm{p}=<0.01$ in the first two cases, $\mathrm{p}=<0.001$ for $600 \mathrm{mg} / \mathrm{kg}$ ). Thus, hydroxyurea had a curative effect on the mice. There was no embryotoxicity or decrease in litter size. The treatment did not induce any other major abnormalities, except that gastroschisis was observed in $3 \%$ of mice treated with $400 \mathrm{mg} / \mathrm{kg}$ and in $5 \%$ of mice given $500 \mathrm{mg} / \mathrm{kg}$. This abnormality is found occasionally in untreated mice.

The results obtained with mitomycin $\mathrm{C}$ are shown in table 2. When administered to the mother on day $9,1 \mathrm{mg} / \mathrm{kg}$ reduced the NTD in the embryos to $43 \%$ $(p=0.05$ to 0.02$)$, while 2,4 , and $6 \mathrm{mg} / \mathrm{kg}$ had a highly significant effect, decreasing the NTD to $15 \%, 19 \%$, and $20 \%$ respectively $(\mathrm{p}=<0.001$ in all cases). Thus, mitomycin $\mathrm{C}$ also had a beneficial effect upon the curly-tail mice. Again, there was no reduction in litter size and no other abnormalities were induced by the treatment.

When 5-fluorouracil was administered to the pregnant curly-tail mouse on day $9,0 \cdot 1,0.25$, and $0.4 \mathrm{mg} / \mathrm{kg}$ did not alter the number of NTD in her offspring (table 3 ). However, with larger doses there was a linear decrease in the incidence of NTD with increasing amounts. With $0.5,0.6,0.7$, and 0.8 $\mathrm{mg} / \mathrm{kg}$, there were $51 \%, 36 \%, 20 \%$, and $13 \%$ respectively of embryos with NTD ( $p=0.05$ to 0.02 for $0.4 \mathrm{mg} / \mathrm{kg}, \mathrm{p}=<0.001$ in all other cases). So 5-fluorouracil also exerts a curative effect on the curly-tail mice. The highest dose was, however, toxic to the embryo, half the total implantations were intrauterine deaths, and the litter size (calculated from the living embryos) was reduced. Further, around $30 \%$ of these living embryos, although having no gross abnormality, were oedematous.

\section{Discussion}

In these experiments, it was observed that a significant proportion of fetal neural tubes genetically programmed to remain open can be made to close by the administration of hydroxyurea, mitomycin C, and 5-fluorouracil to the mother on day 9 of pregnancy. Since these are cytotoxic agents, they are somewhat surprising candidates for 'curative agents' during embryogenesis.

Such a curative effect on day 9 had also been observed previously with vitamin A. ${ }^{10}$ However, the primary effect of vitamin $A$ is not known; its secondary effects are wide-ranging and found in both ectodermal and mesodermal derivatives, and it produces many different abnormalities in the curlytail and other mice. For these reasons, vitamin $A$ is omitted from considerations relative to this hypothesis. Hydroxyurea, mitomycin $\mathrm{C}$, and 5-fluorouracil, by contrast, on the whole do not produce any other significant abnormalities in the curly-tail mice. Further, their primary site of action is known and they all have a common denominator in that they are inhibitors of DNA synthesis, although acting at different points in the biosynthetic pathway. Hydroxyurea specifically inhibits the enzyme ribonucleotide reductase. ${ }^{17}$ This blocks the production of all deoxyribonucleotides and hence inhibits DNA synthesis. Secondary effects are inhibition of cell division, with cells in the $S$ phase of mitosis being irreversibly damaged and becoming necrotic. ${ }^{18}$ Mitomycin $\mathrm{C}$ induces cross-linking of the complementary strands of the DNA molecule ${ }^{19}$ and thus interferes with DNA replication and leads to cell death, yet apparently has little effect on the ability of the DNA to direct the synthesis of proteins. 5-fluorouracil specifically inhibits thymidylate synthetase and so prevents the formation of deoxythymidylic acid, one of the four deoxyribonucleotides involved in DNA synthesis before cell replication, from its precursor, deoxyuridylic acid. ${ }^{20}$

In the experiments described in the curly-tail mice, it was when the identical unexpected findings were obtained with both hydroxyurea and mitomycin $\mathrm{C}$ that it was wondered whether inhibition of DNA synthesis was a cardinal point. From these two series of experiments, it appeared that in the curly-tail mouse, if DNA synthesis could be reversibly inhibited for a time, then significant prevention of 
the occurrence of NTD could be achieved. So it was then predicted that if another inhibitor of DNA synthesis was used it would have the same effect. Consequently, 5-fluorouracil was selected and tested and found to bear out the prediction.

One plausible explanation for these findings is that the NTD in the curly-tail mice arise from a dyssynchrony of DNA synthesis. More specifically, it could be that NTD arise in those embryos which have delayed DNA synthesis, because of a basic metabolic defect in the biosynthetic pathway of DNA, whereby lower than normal amounts of one of the metabolites necessary for the biosynthesis of DNA occur. This could be critical to rapidly growing tissues relying for normal morphogenesis on speedy cell division. This delay in DNA synthesis could in turn cause fewer than normal cells to be produced so that morphogenesis of the CNS is delayed and thus cannot be completed correctly. If this is so, it could follow that this deficiency can be made good if DNA synthesis is reversibly inhibited for a time to allow accumulation of that essential metabolite. If development is transiently arrested at a critical time (administration of DNA inhibitors on day 8 was not beneficial, ${ }^{16}$ on day 9 markedly effective), the cells are brought into line and normal development ensues, at the price of a total developmental delay, from which it appears possible to recover without obvious detrimental consequence (although mitomycin $\mathrm{C}$ might not be without some long term effects manifest postnatally ${ }^{21}$ ).

Experimental zinc deficiency in rats seems to give support to the hypothesis outlined here. When zinc deficiency is induced in pregnant rats, CNS and other abnormalities result in the offspring. Although hydrocephalus is the most common defect produced, NTD also occur. ${ }^{22}$ The embryos of such mothers have depressed synthesis of $\mathrm{DNA}^{23}$ and there is a regional difference in the rate of DNA synthesis within the embryo; further maternal administration of zinc will reverse this. ${ }^{24}$ Eckhert and Hurley ${ }^{24}$ have suggested that these zinc induced congenital abnormalities are produced by asynchronous differential growth rates which result from depressed DNA synthesis.

In line with the hypothesis proposed to explain the experimental findings in the curly-tail mice, albeit speculative, I suggest that the cause of NTD in man is similarly a basic metabolic defect in the biosynthetic pathway of DNA. Such a suggestion is not inconsistent with the clinical observations that pregnant women with NTD fetuses have low blood levels of folate, ${ }^{25}$ zinc, ${ }^{26}$ and vitamin $\mathrm{B}_{12},{ }^{27}$ or with the findings in women that periconceptional multivitamin $^{23}$ or folate ${ }^{4}$ supplementation prevents the recurrence of NTD. Folate, vitamin $B_{12}$, zinc, and other vitamins are intimately involved, directly or indirectly, in the biosynthesis of DNA and its precursors.

The experimental work described here was carried out with the aid of generous financial assistance from Action Research-The National Fund for Research into Crippling Diseases. I thank Kathy J Perkins for technical assistance.

\section{References}

1 Carter CO. Clues to the aetiology of neural tube malformations. Dev Med Child Neurol 1974;16:3-15.

2 Smithells RW, Sheppard S, Schorah CJ, et al. Possible prevention of neural tube defects by periconceptional vitamin supplementation. Lancet $1980 ; \mathbf{i}: 339-40$.

3 Smithells RW, Sheppard S, Schorah CJ, et al. Vitamin supplementation and neural tube defects. Lancet 1981; ii : 1425 .

4 Laurence KM, James N, Miller MH, Tennant GB, Campbell H. Double-blind randomised controlled trial of folate treatment before conception to prevent recurrence of neural-tube defects. Br Med J 1981;282:1509-11.

5 Copp AJ, Seller MJ, Polani PE. Neural tube development in mutant (curly-tail) and normal mouse embryos: the timing of posterior neuropore closure in vivo and in vitro. $J$ Embryol Exp Morphol 1982;69:151-67.

6 Grüneberg H. Genetical studies on the skeleton of the mouse. VIII. Curly-tail. J Genet 1954;52:52-67.

7 Embury S, Seller MJ, Adinolfi M, Polani PE. Neural tube defects in curly-tail mice. I. Incidence, expression and similarity to the human condition. Proc $R$ Soc Lond (Biol) 1979;206:85-94.

8 Seller MJ, Adinolfi M. The curly-tail mouse: an experimental model for human neural tube defects. Life Sci 1981;29:1607-15.

9 Adinolfi M, Beck S, Embury S, Polani PE, Seller MJ. Levels of $a$-fetoprotein in amniotic fluids of mice (curlytail) with neural tube defects. J Med Genet 1976;13: 511-3.

10 Seller MJ, Embury S, Polani PE, Adinolfi M. Neural tube defects in curly-tail mice. II. Effects of maternal administration of vitamin A. Proc R Soc Lond (Biol) 1979; 206:95-107.

11 Seller MJ, Beck SE, Adinolfi M, Polani PE. Maternal environment and the expression of murine neural tube defects. Prenatal Diagnosis $1981 ; 1: 103-5$.

12 Seller MJ. An essay on research into the causation and prevention of spina bifida. $Z$ Kinderchir 1981;34:306-14.

13 Seller MJ, Perkins KJ. Prevention of neural tube defects in curly-tail mice by maternal administration of vitamin A. Prenatal Diagnosis 1982;2:297-300.

14 Seller MJ, Perkins KJ, Adinolfi M. Differential response of heterozygous curly-tail mouse embryos to vitamin A teratogenesis depending on maternal genotype. Teratology (in press).

15 Seller MJ. Neural tube defects: cause and prevention. In: Adinolfi M, Benson PF, Giannelli F, Seller MJ, eds. Paediatric research: a genetic approach. London: Spastics International Medical Publications, 1982:197-211.

16 Seller MJ, Perkins KJ. Effect of hydroxyurea on neural tube defects in the curly-tail mouse. J Craniofac Genet Dev Biol (in press).

17 Young CW, Hodas S. Hydroxyurea: inhibitory effect on DNA metabolism. Science 1964;146:1172-4. 
18 Herken R. Cell cycle phase specificity of hydroxyurea and its effects on the cell kinetics in embryonic spinal cord. Teratology 1980;21:9-14.

19 Iyer VN, Szybalski W. A molecular mechanism of mitomycin action: linking of complementary DNA strands. Proc Natl Acad Sci USA 1963;50:355-62.

20 Langenbach RJ, Danenberg PV, Heidelberger C. Thymidylate synthetase: mechanism of inhibition by 5-fluoro2'-deoxyuridylate. Biochem Biophys Res Commun 1972; 48:1565-71.

21 Snow MHL, Tam PPL. Is compensatory growth a complicating factor in mouse teratology? Nature 1979; 279:555-7.

22 Hurley LS, Shrader RE. Congenital malformations of the nervous system in zinc-deficient rats. In: Pfeiffer CC, ed. Neurobiology of the trace metals zinc and copper. New York, London: Academic Press, 1972:7-51.
${ }^{23}$ Swenerton H, Shrader R, Hurley LS. Zinc-deficient embryos: reduced thymidine incorporation. Science 1969; 166:1014-5.

24 Eckhert CD, Hurley LS. Reduced DNA synthesis in zinc deficiency: regional differences in embryonic rats. $J$ Nutr 1977;107:855-61.

${ }^{25}$ Smithells RW, Sheppard S, Schorah CJ. Vitamin deficiencies and neural tube defects. Arch Dis Child 1976; $51: 944-50$.

26 Cavdar AO. Zinc and small babies. Lancet 1982;i:339-40.

${ }^{27}$ Schorah CJ, Smithells RW, Scott J. Vitamin $B_{12}$ and anencephaly. Lancet 1980;i:880.

Correspondence and requests for reprints to Dr M J Seller, Paediatric Research Unit, Guy's Hospital Medical School, London SE1 9RT. 